\title{
The priority of maintaining the reliability of sustainable construction at the Ampel Mosque Surabaya
}

\author{
Agung Sedayu ${ }^{1, *}$ \\ ${ }^{1}$ Department of Architecture Engineering, Faculty of Science and Technology, Maulana Malik Ibrahim \\ State Islamic University of Malang
}

\begin{abstract}
The Ampel Mosque was founded in 1421 by Raden Mohammad Ali Rahmatullah (Sunan Ampel). The Ampel Mosque is located in Ampel Village, Semampir subdistrict, Surabaya City, East Java, Indonesia. The Ampel Mosque was built with a Javanese architectural style and nuances of Arabian Islam. The mosque is influenced by the acculturation of local culture (local wisdom) and Hindu-Buddhism as seen in the architecture of the building. This study aims to determine the priority of maintaining the reliability of sustainable construction at the Ampel Mosque. The method used was Importance Performance Analysis (IPA) and Quality Function Deployment (QFD). The data obtained from the research concluded that the highest demand requirements are the convenience and accessibility levels, in terms of structural components' maintainability. The highest priority variable to be increased is non-hazardous building materials. The highest target is the guarantee of the design and configuration of nonhazardous construction systems. These variables can be considered in the repair and improvement of the maintenance of the Ampel Mosque by the mosque management institution.
\end{abstract}

\section{Introduction}

The Ampel Mosque Surabaya was founded in 1421 by Raden Mohammad Ali Rahmatullah (Sunan Ampel). In this area, Sunan Ampel also established Islamic Boarding Schools as Islamic Education Centers in Surabaya and Java. The Ampel Mosque was built in Javanese and Arabic architectural styles, and now has developed an expansion of the mosque building and the arrangement of Sunan Ampel's tomb area. The architecture and typology of the building of this mosque is influenced by the acculturation of local culture (local wisdom) and Hindu-Buddhism. This mosque, at that time, became a gathering place of scholars and guardians from various regions in Java to discuss Islamic teachings as well as the method of Islamic dissemination on Java.

*Corresponding author: uinsedayu@gmail.com 


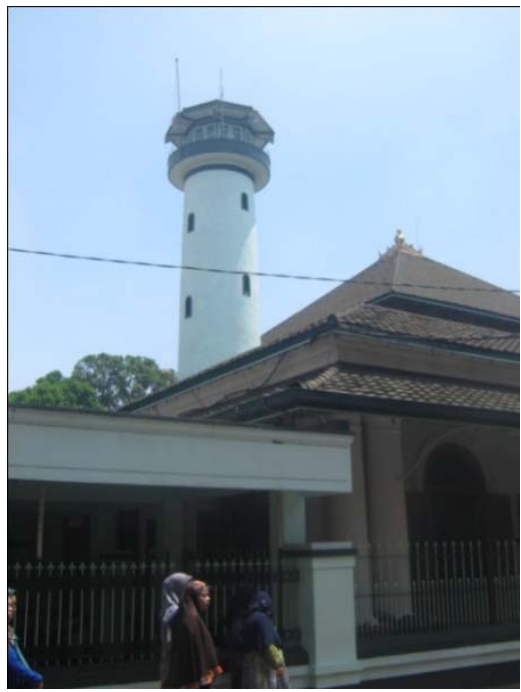

Fig. 1. The tower of Ampel Mosque.

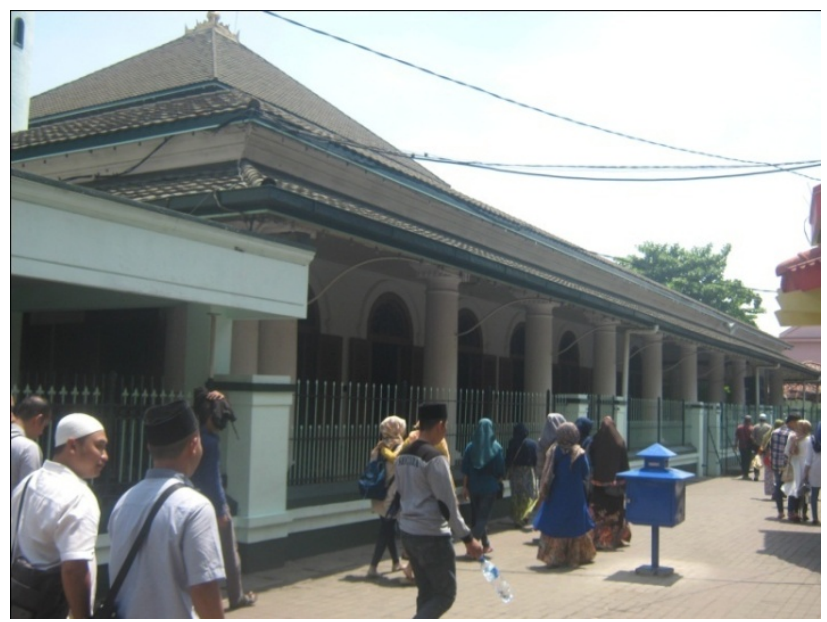

Fig. 2. The side of Ampel Mosque.

The Ampel Mosque roof frame is made of teak wood and the bearing wall from brick. Until 2017, the Ampel Mosque has undergone many changes in the used materials, technology and construction. For the roof some parts are replaced with reinforced concrete and steel, and bearing walls were replaced with rigid reinforced concrete frames with partition walls of $\pm 15 \mathrm{~cm}$ thick bricks. Some pictures of the existing condition of the Ampel Mosque (2017) are shown in Figures 1 and 2. Figure 2 shows the original construction of the mosque made of teak wood while Figure 3 shows the new mosque construction using reinforced concrete. This study aims to determine the priority of maintaining the sustainability of the Ampel Mosque construction. The maintenance priority considers user perceptions, which includes those of people who congregate in the mosque and communities around the mosque. This consideration is used to assess and evaluate the technical aspects of the mosque, especially the construction system used. 


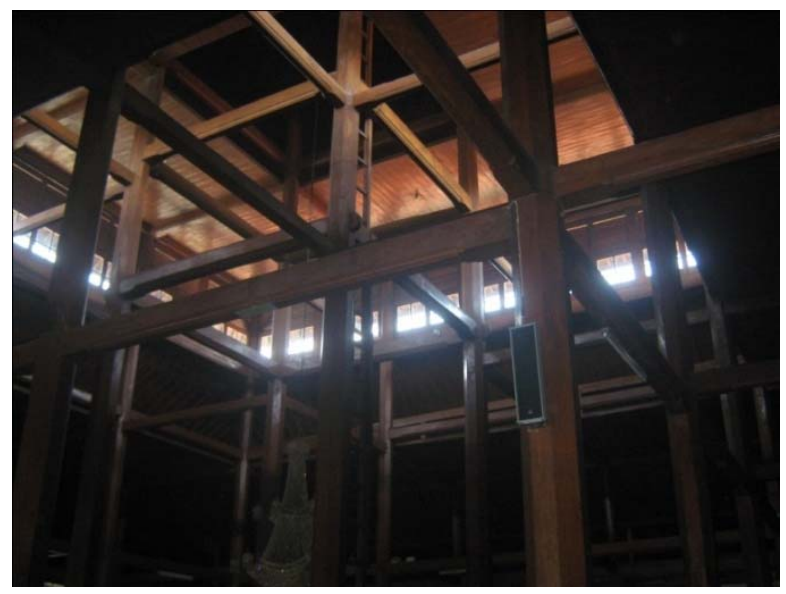

Fig. 3. The combination of columns and beams as the supporting frame.

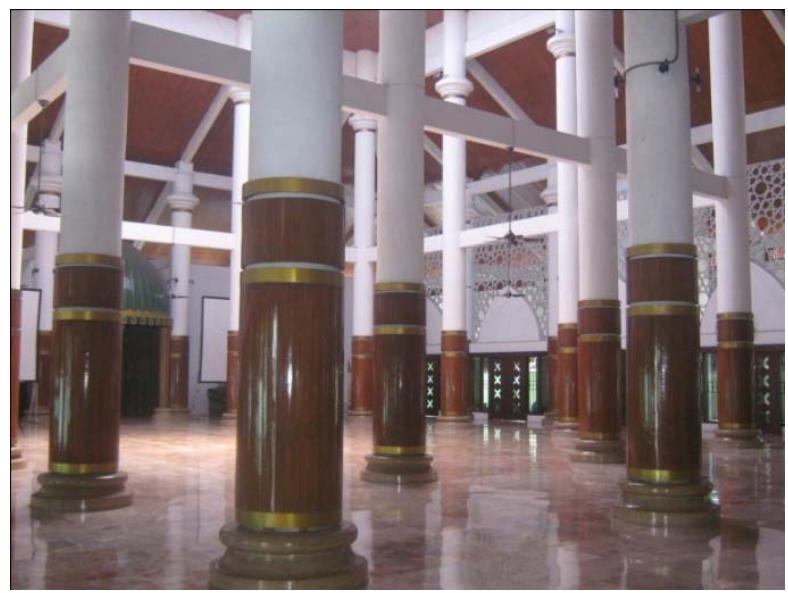

Fig. 4. The main room of the mosque which is included in the development area of the Ampel Mosque.

\section{Materials and methods}

The data used as instrument for research purposes was prepared through previous studies. Maintenance factors were obtained from the study of previous research variables with additions and adjustments to the existing condition of the mosque. Table 1 describes the previous research works.

Table 1. Previous researches.

\begin{tabular}{|c|l|l|l|l|l|}
\hline No & Researcher & Year & \multicolumn{1}{c|}{ Topic } & \multicolumn{1}{c|}{ Method } & \multicolumn{1}{c|}{ Variable } \\
\hline 1 & Wayne [1] & 2013 & $\begin{array}{l}\text { The Use of LCA in } \\
\text { determining the } \\
\text { Green Building } \\
\text { rating }\end{array}$ & $\begin{array}{l}\text { Life Cycle } \\
\text { Assessment } \\
\text { (LCA) and } \\
\text { modelling by } \\
\text { using software }\end{array}$ & $\begin{array}{l}\text { Building material, } \\
\text { energy usage, } \\
\text { environment, } \\
\text { building element }\end{array}$ \\
\hline
\end{tabular}




\begin{tabular}{|c|c|c|c|c|c|}
\hline No & Researcher & Year & $\begin{array}{c}\text { Topic } \\
\end{array}$ & Method & Variable \\
\hline 2 & Huda [2] & 2013 & $\begin{array}{l}\text { The factor and } \\
\text { criteria analysis and } \\
\text { evaluation of Green } \\
\text { Building }\end{array}$ & $\begin{array}{l}\text { Field } \\
\text { measurement, } \\
\text { qualitative and } \\
\text { quantitative, } \\
\text { observation and } \\
\text { Green ship } \\
\text { standard } \\
\text { ranking }\end{array}$ & $\begin{array}{l}\text { Appropriate Site } \\
\text { Development, } \\
\text { Energy Efficiency } \\
\text { and Refrigerant, } \\
\text { Water } \\
\text { Conservation, } \\
\text { Indoor Air Health } \\
\text { and Comfort, } \\
\text { Building and } \\
\text { Environment } \\
\text { Management, } \\
\text { Material Resources } \\
\text { and Cycle, }\end{array}$ \\
\hline 3 & $\begin{array}{l}\text { Hariningsih } \\
\text { [3] }\end{array}$ & 2013 & $\begin{array}{l}\text { Knowing guests' } \\
\text { responses about } \\
\text { physical facilities } \\
\text { consist of building, } \\
\text { technology (devices } \\
\text { and equipment), } \\
\text { room and restaurant } \\
\text { in the hotel building } \\
\end{array}$ & $\begin{array}{l}\text { Accidental } \\
\text { sampling and } \\
\text { linear regression } \\
\text { analysis }\end{array}$ & $\begin{array}{l}\text { Physical facility } \\
\text { availability, physic, } \\
\text { dimension and } \\
\text { specification and } \\
\text { maintenance }\end{array}$ \\
\hline 4 & $\begin{array}{l}\text { Abimaje et. } \\
\text { al [4] }\end{array}$ & 2014 & $\begin{array}{l}\text { Wood evaluation as } \\
\text { the sustainable } \\
\text { material in Nigeria }\end{array}$ & $\begin{array}{l}\text { Survey and } \\
\text { investigation, } \\
\text { literature Study, } \\
\text { and comparative } \\
\text { study }\end{array}$ & $\begin{array}{l}\text { Workability, } \\
\text { Durability, low } \\
\text { thermal } \\
\text { conductivity, } \\
\text { preservative } \\
\text { treatments, and fire } \\
\text { retardant and } \\
\text { afforestation }\end{array}$ \\
\hline 5 & $\begin{array}{l}\text { Carsten Hein } \\
\text { [5] }\end{array}$ & 2014 & $\begin{array}{l}\text { Construction hybrid } \\
\text { timber on the high } \\
\text { building }\end{array}$ & $\begin{array}{l}\text { Modelling with } \\
\text { software and } \\
\text { technical } \\
\text { analysis from } \\
\text { previous studies }\end{array}$ & $\begin{array}{l}\text { Embodied energy, } \\
\text { Low carbon, and } \\
\text { Sustainability }\end{array}$ \\
\hline 6 & $\begin{array}{l}\text { Komalasari } \\
{[6]}\end{array}$ & 2014 & $\begin{array}{l}\text { The assessment of } \\
\text { Green Building } \\
\text { based on energy } \\
\text { efficiency and } \\
\text { conservation }\end{array}$ & $\begin{array}{l}\text { Comparative } \\
\text { Study, } \\
\text { modelling by } \\
\text { using software, } \\
\text { and direct } \\
\text { measurement }\end{array}$ & $\begin{array}{l}\text { Energy Efficiency } \\
\text { Measure, Natural } \\
\text { and artificial } \\
\text { Lighting, } \\
\text { Ventilation, Climate } \\
\text { Change Impact, } \\
\text { Vertical } \\
\text { transportation, and } \\
\text { Air condition } \\
\text { system }\end{array}$ \\
\hline 7 & $\begin{array}{l}\text { Adebara et. } \\
\text { al [7] }\end{array}$ & 2014 & $\begin{array}{l}\text { Analysis on timber } \\
\text { influence as the } \\
\text { building } \\
\text { construction material }\end{array}$ & $\begin{array}{l}\text { Investigated and } \\
\text { Ranking and } \\
\text { Quality control } \\
\text { measures }\end{array}$ & $\begin{array}{l}\text { Over cultivation, } \\
\text { Poor irrigation } \\
\text { practices, Domestic } \\
\text { purposes, } \\
\text { Deforestation, } \\
\text { Economic } \\
\text { productivity of the } \\
\text { land, Resulting to } \\
\text { the loss of } \\
\text { biological }\end{array}$ \\
\hline
\end{tabular}




\begin{tabular}{|c|c|c|c|c|c|}
\hline No & Researcher & Year & Topic & Method & Variable \\
\hline 8 & Sugiama [8] & 2015 & $\begin{array}{l}\text { Quality service } \\
\text { modelling at the } \\
\text { green open space }\end{array}$ & $\begin{array}{l}\text { Importance } \\
\text { Performance } \\
\text { Analysis (IPA), } \\
\text { Focus Group } \\
\text { Discussion } \\
\text { (FGD), and } \\
\text { Quality } \\
\text { Function } \\
\text { Deployment } \\
\text { (QFD) }\end{array}$ & $\begin{array}{l}\text { Water conservation, } \\
\text { Environmental } \\
\text { aesthetics, Air } \\
\text { conservation, } \\
\text { Overcome water } \\
\text { disasters. }\end{array}$ \\
\hline 9 & $\begin{array}{l}\text { Kusumawar } \\
\text { dani, } \\
\text { Suryasari, } \\
\text { and } \\
\text { Antariksa [9] }\end{array}$ & 2016 & $\begin{array}{l}\text { Component } \\
\text { Description on the } \\
\text { Façade element of } \\
\text { Malang Great } \\
\text { Mosque }\end{array}$ & $\begin{array}{l}\text { Observation, } \\
\text { Qualitative, } \\
\text { Descriptive }\end{array}$ & $\begin{array}{l}\text { Form, shape, } \\
\text { dimension, } \\
\text { Material, Color, and } \\
\text { Texture }\end{array}$ \\
\hline 10 & Sedayu [10] & 2016 & $\begin{array}{l}\text { Working } \\
\text { performance } \\
\text { evaluation of green } \\
\text { building in "pondok } \\
\text { pesantren" (Islamic } \\
\text { Boarding School) }\end{array}$ & $\begin{array}{l}\text { Importance- } \\
\text { Performance } \\
\text { Analysis (IPA) } \\
\text { and Quality } \\
\text { Function } \\
\text { Deployment } \\
\text { (QFD) }\end{array}$ & $\begin{array}{l}\text { Sustainable Earth } \\
\text { friendly and High- } \\
\text { performance } \\
\text { building }\end{array}$ \\
\hline
\end{tabular}

Standardized research instruments are distributed to respondents for analysis. Stages of analysis of this study include:

\section{A. Importance-performance analysis (IPA)}

Importance-Performance Analysis (IPA) is conducted to obtain the level of importance of the user to the maintenance of the reliability of the construction. The level of importance of the user is described in the importance classification diagram which is divided into four quadrants (Figure 4) with the following explanation:

a. Quadrant A, an area containing factors that are considered important by the users, but with very low levels of user satisfaction. In this area the managers make continuous improvements to improve performance.

b. Quadrant B, an area containing factors that are considered important by the users, with high levels of satisfaction.

c. Quadrant C, an area that contains factors that are considered less important by users, and in fact are less important.

d. Quadrant D, an area containing factors that are considered less important by users, and which felt overrated. 


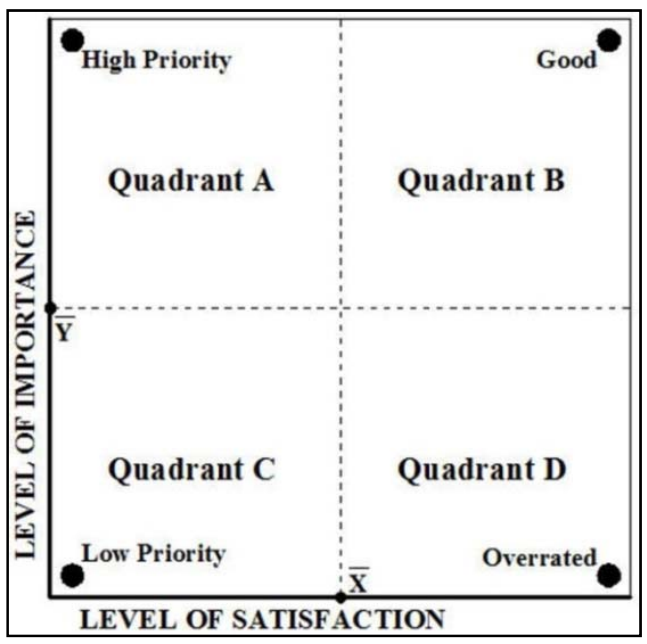

Fig. 4. Importance classification diagram.

Source: Sedayu, 2014 [11]

B. Quality function deployment (QFD)

Quality Function Deployment (QFD) is used to know the target of improvement of the mosque construction reliability according to users. A house of quality (HoQ), which is part of the QFD analysis, as shown in Figure 5.

\begin{tabular}{|c|c|c|}
\hline & $\begin{array}{c}\text { Part C } \\
\text { technical characteristic }\end{array}$ & \\
\hline \multirow[t]{2}{*}{$\begin{array}{c}\text { Part A } \\
\text { user's need and wish }\end{array}$} & $\begin{array}{l}\text { Part D } \\
\text { the relationship (characteristic } \\
\text { influence on the user's needs) }\end{array}$ & $\begin{array}{c}\text { Part B } \\
\text { planning matrix (market survey } \\
\text { and strategic planning) }\end{array}$ \\
\hline & $\begin{array}{c}\text { Part F } \\
\text { technical matrix (technical } \\
\text { characteristic priority } \\
\text { compared to target competitor }\end{array}$ & \\
\hline
\end{tabular}

Fig. 5. House of quality in QFD.

Source: Sedayu, 2016 [12]

The research respondents were the users of Ampel Mosque. The reasons for the use of this type of sampling, are because the elements of the population are characterized as heterogeneous, and heterogeneity has a significant influence on the achievement of research objectives. Determination of the research samples is done through the Bernoulli equation:

$$
\mathrm{N} \geq \frac{\left(\mathrm{Z}_{\mathrm{a} / 2}\right)^{2} \mathrm{p} \cdot \mathrm{q}}{\mathrm{e}^{2}}
$$

so be $\mathrm{N} \geq 72,99 \approx 73$ 
With $\mathrm{N}=$ minimum sample quantity; $\mathrm{Z}=$ normal distribution value; $\mathrm{e}=$ error rate; $\mathrm{p}=$ the proportion of the number of questionnaires are considered correct; and $\mathrm{q}=$ the proportion of the number of questionnaires considered incorrect. If the correct value is $95 \%$, then the number of questionnaires considered incorrect is 5\%. To avoid the lack of data due to error filling or no return of questionnaires, it was decided to use 75 respondents. Stages in the QFD analysis include:

a) Customer Satisfaction Performance: the user's assessment for how well the services of the management for the users or the management provided to the user. The formula is:

$$
\begin{gathered}
\text { Weight Average Performance }(W A P)=\frac{\sum \text { Performane Weight }(\mathrm{PW})}{\text { Numberof } \operatorname{Respondent}(\mathrm{N})}= \\
=\frac{\sum(\text { Level of satisfaction }) \mathrm{x} \text { Number of respondent }}{\text { Number of respondent }}
\end{gathered}
$$

b) User Expected Performance: part of user expected performance is

$$
\begin{gathered}
\text { Weight Average Performance }(W A P)=\frac{\sum \text { Expected Performance Weight (EPW) }}{\text { Number of Respondent }(\mathrm{N})} \\
=\frac{\sum(\text { Levelof expected performance }) \mathrm{x} \text { Number of respondent }}{\text { Number of respondents }}
\end{gathered}
$$

c) Gap of negative value indicates the problems faced by the manager so that they need to be improved in order to improve the quality of service.

d) Goal: the level of expected satisfaction performance to be achieved by the manager or management to meet each user's wishes.

e) Improvement Ratio (IR): a measurement of how much should be done by the manager or management as an effort to improve the quality of service. IR formula:

$$
I R=\frac{\text { Goal }}{\text { User Satisfaction Performance }}
$$

f) Sales Point is determined by the manager. This value reflects the ability to sell services and products based on how well each user's desires can be met. The scale for the Sales Point is:

- 1.0 indicates no point of sale

- 1.2 indicates the middle selling point

- 1.5 shows strong sales

g) Raw Weight (RW) contains the calculated value of data and decisions made during the preparation of the planning matrix. The value of Raw Weight for each user need is:

$$
\text { Raw Weight }=(\text { Importance to User) } x \text { (Improvement Ratio) } x(\text { Sales Point })
$$

h) Normalized Raw Weight (NRW) containing Raw Weight (RW) is scaled to a design between 0 and 1 or expressed in percentage.

$$
\text { Normalized Raw Weight }(N R W)=\frac{\text { Raw Weight }(\mathrm{RW})}{\text { Total of Raw Weight }}
$$

i) Technical Response is the result of discussion of researchers and managers that must be owned by Ampel Mosque according to the users' input. 
j) The Relationship Matrix and Priority reflect the technical response influence on the handling and regulations of the major necessities in terms of user satisfaction degree.

Table 2. Relationship matrix symbols.

\begin{tabular}{|l|c|c|}
\hline \multicolumn{1}{|c|}{ Meaning of symbols } & Symbol & Numerical Value (Num) \\
\hline No relationship & Empty & 0 \\
\hline Weak relationship & - & 1 \\
\hline Moderate Relationship & & 3 \\
\hline Strong Relationship & & 9 \\
\hline
\end{tabular}

Source: Sedayu, 2016 [12]

k) The priority value illustrates the contribution of the technical response to the fulfilment of user desires.

Contribution (Cont) $=\Sigma$ Normalized Raw Weight $x$ Numerical Value of Relationship Matrix

1) Contribution value or normalized contribution (NC): priority and technical responses in scale 0 to 1 that indicates the percentage to be obtained. The formula is:

$$
\text { Normalized contribution }(N C)=\frac{\text { Cont }}{\text { Total Cont }}
$$

With description, Cont $=$ contribution

m) Own Performance (OP) can be calculated using the following formula:

$$
O P=\frac{\sum(\mathrm{USP} \times \mathrm{nv})}{\sum \mathrm{nv}}
$$

With description, $U S P=$ user satisfaction performance, $n v=$ numerical value

n) Preparation of affinity diagram that describes the classification of maintenance target of mosque construction reliability.

\section{Result and discussion}

\subsection{Description of field survey result}

The result of the field survey with Voice of User to determine the instrument of research is shown in Table 3. Respondents targeted by this survey were 30 people. 
Table 3. The research variables in voice of user.

\begin{tabular}{|c|l|c|c|}
\hline No & \multicolumn{1}{|c|}{ Research variables } & Mean & Rank \\
\hline 1 & $\begin{array}{l}\text { Ease of construction work (Workability) with easy and inexpensive } \\
\text { technology }\end{array}$ & 3,821 & 3 \\
\hline 2 & Serviceability that is reliable and superior in supporting construction & 3,774 & 6 \\
\hline 3 & Durability of building construction within the service life of the plan & 3,795 & 5 \\
\hline 4 & Guaranteed security and safety during the functioning of the building & 3,818 & 4 \\
\hline 5 & $\begin{array}{l}\text { Aesthetics visual architectural systems and building construction } \\
\text { materials }\end{array}$ & 3,726 & 7 \\
\hline 6 & $\begin{array}{l}\text { Comfort and regularity in physical and psychical aspects during the } \\
\text { functioning of building construction }\end{array}$ & 3,723 & 8 \\
\hline 7 & $\begin{array}{l}\text { Ease and affordability in maintenance (Maintainability) of construction } \\
\text { components }\end{array}$ & 3,927 & 1 \\
\hline 8 & $\begin{array}{l}\text { Quality of maintenance performed on the architectural and structural } \\
\text { components of the building }\end{array}$ & 3,877 & 2 \\
\hline
\end{tabular}

A validity test was done to determine the validity of the questionnaire to be distributed to people as the research sample. This test was conducted on 30 people as the minimum respondents in a trial [13]. In this study, an instrument is said to be strongly correlated if the correlation value is above 0.6 [13]. Reliability tests were performed to determine whether the data collection tool basically shows the level of accuracy, stability, or consistency of the tool in revealing certain symptoms of a group of individuals, albeit at different times. The reliability test is performed on strongly correlated statements. To test Internal Consistency is done by using a coefficient of consistency (Alpha Cronbach), provided that the coefficient of the alpha value (Alpha Cronbach coefficient) is above 0.60 [13]. This validity and reliability test use the statistical analysis program of SPSS 20.0. The results of the validity and reliability test are shown in Table 4.

Table 4. Test results validity and reliability research instruments.

\begin{tabular}{|c|l|c|c|}
\hline No & Variable & $\begin{array}{c}\text { Validity Test } \\
\text { (correlation value) }\end{array}$ & $\begin{array}{c}\text { Reliability Test } \\
\text { (alpha value) }\end{array}$ \\
\hline 1 & Level of User's Satisfaction (KP) & $>0,6$ & $0,961(>0,6)$ \\
\hline 2 & Level of User's Importance (TK) & $>0,6$ & $0,877(>0,6)$ \\
\hline 3 & Levels of User's Expectation (HP) & $>0,6$ & $0,923(>0,6)$ \\
\hline
\end{tabular}

From Table 4, it appears that the validity and reliability test for 7 research variables is valid and reliable. These results state that the instrument can be used at a later stage in collecting and analyzing data. The results of data collection with this instrument can be used in further in-depth analysis.

\subsection{Results importance-performance analysis (IPA)}

Table 5 is the recapitulation of mean values for level of users' satisfaction (KP) with the importance level (TK) of Ampel Mosque building component. The gap value is the difference between KP and TK, namely KP - TK. Negative gap values require attention in the priority of the improvement of the components of the mosque building, depending on the level of the importance and the satisfaction scores have obtained the above average score or not. 
Table 5. Results of IPA on the importance and satisfaction of Ampel Mosque Surabaya.

\begin{tabular}{|c|c|c|c|c|}
\hline \multirow{2}{*}{ No } & \multirow{2}{*}{ Maintaining Reliability Construction Factors } & \multicolumn{2}{|c|}{ Mean Value } & \multirow{2}{*}{ Gap } \\
\hline & & KP & TK & \\
\hline 1 & Construction work & 3,703 & 3,631 & 0,072 \\
\hline 2 & Construction equipment & 3,630 & 3,547 & 0,083 \\
\hline 3 & Construction Labor & 3,852 & 3,832 & 0,020 \\
\hline 4 & Financing the implementation & 3,878 & 3,856 & 0,022 \\
\hline 5 & Management of work & 3,885 & 3,926 & $-0,041$ \\
\hline 6 & Equilibrium system of construction & 3,614 & 3,566 & 0,048 \\
\hline 7 & Stability of construction system & 3,619 & 3,875 & $-0,256$ \\
\hline 8 & Strength of construction system & 3,832 & 3,669 & 0,163 \\
\hline 9 & Proportional and system construction configuration & 3,729 & 3,768 & $-0,039$ \\
\hline 10 & Durability to functional damage level & 3,591 & 3,879 & $-0,288$ \\
\hline 11 & Service time or work function & 3,878 & 3,772 & 0,106 \\
\hline 12 & Level of damage visually & 3,626 & 3,837 & $-0,211$ \\
\hline 13 & $\begin{array}{l}\text { Guarantees of free from physical and psychological dangers of } \\
\text { construction function }\end{array}$ & 3,419 & 3,729 & $-0,310$ \\
\hline 14 & Non-hazardous building materials & 3,498 & 3,974 & $-0,476$ \\
\hline 15 & Design and configuration of non-hazardous construction systems & 3,544 & 3,958 & $-0,414$ \\
\hline 16 & Implementation and maintenance of non-hazardous construction & 3,489 & 3,867 & $-0,378$ \\
\hline 17 & Aesthetics of structural materials & 4,014 & 3,782 & 0,232 \\
\hline 18 & System aesthetics and construction configurations & 3,648 & 3,733 & $-0,085$ \\
\hline 19 & Aesthetics of architectural material & 3,872 & 3,845 & 0,027 \\
\hline 20 & Aesthetic details of construction craft & 3,858 & 3,878 & $-0,020$ \\
\hline 21 & Comfort and regularity of physical and psychic buildings & 3,699 & 3,832 & $-0,133$ \\
\hline 22 & Regularity of system configuration and building construction & 3,576 & 3,866 & $-0,290$ \\
\hline 23 & Regularity of building construction material system & 3,915 & 3,658 & 0,257 \\
\hline 24 & Regularity of non-structural materials in the construction system & 3,845 & 3,815 & 0,030 \\
\hline 25 & Comfort and regularity of outdoor design & 3,496 & 3,911 & $-0,415$ \\
\hline 26 & Ease and affordability of maintenance & 3,673 & 3,725 & $-0,052$ \\
\hline 27 & Availability of maintenance labor & 3,832 & 3,754 & 0,078 \\
\hline 28 & Availability of maintenance costs & 3,612 & 3,644 & $-0,032$ \\
\hline 29 & Management of maintenance & 3,842 & 3,846 & $-0,004$ \\
\hline 30 & Maintenance methods are easy to understand and apply & 3,667 & 3,851 & $-0,184$ \\
\hline
\end{tabular}

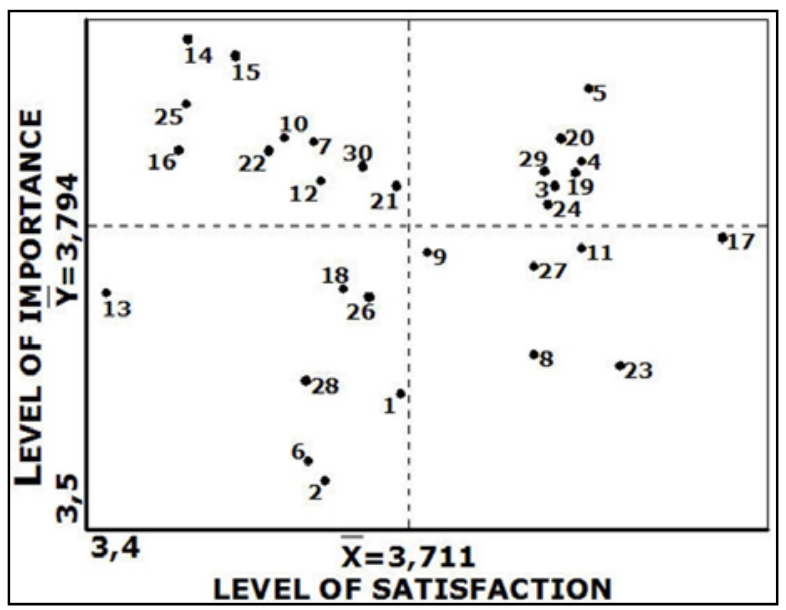

Fig. 6. Importance-satisfaction classification diagram of Ampel Mosque.

The mean value for user's satisfaction (KP) is $\mathrm{X}=3.711$ and the level of user's importance (TK) $\mathrm{Y}=3.794$. The mean values in Table 5 are further plotted into the users' 
importance-satisfaction classification diagram as shown in Figure 6. The plot results in Figure 6 are shown in Table 6 in accordance with the priority level of quality improvement of the Ampel Mosque building components according to the level of importance and users' satisfaction.

Table 6. Priority level of maintenance improvement of Ampel Mosque Surabaya.

\begin{tabular}{|l|l|l|}
\hline \multicolumn{2}{|c|}{ Quadrant } & Reliability Factor Notation \\
\hline A & : High Priority & $14 ; 15 ; 25 ; 10 ; 7 ; 16 ; 22 ; 30 ; 12 ; 21$ \\
\hline B & $:$ Good & $5 ; 20 ; 4 ; 29 ; 19 ; 3 ; 24$ \\
\hline C & $:$ Low Priority & $2 ; 6 ; 1 ; 28 ; 26 ; 13 ; 18$ \\
\hline D & $:$ Overrated & $23 ; 8 ; 27 ; 9 ; 11 ; 17$ \\
\hline
\end{tabular}

From Figure 6 and Table 6 it appears that 10 variables have a high priority for improvement, i.e. non-hazardous building materials (no.14), Design and configuration of non-hazardous construction systems (no.15), Comfort and regularity of outdoor design (no. 25), Durability to functional damage level (no.10), Stability of construction system (no.7), Implementation and maintenance of non-hazardous construction (no.16), Regularity system configuration and building construction (no.22), Maintenance methods are easy to understand and apply (no.30), Level of damage visually (no.12), and Comfort and regularity of physical and psychic building (no.21).

\subsection{Result quality function deployment (QFD)}

Quality Function Deployment (QFD) analysis aims to determine the target of quality improvement of mosque building component by measuring the value of Own Performance (OP) of technical response of the manager or mosque management. Whenever the OP values are high, the targeted enhancement response will be high as well.

The target sequence corresponds to the value of the OP's technical response rating. QFD analysis conducted at the Ampel Mosque determines the difference value (gap) between users' satisfaction (KP) and users' expectations (HP). A negative value gap indicates problems faced by the manager, so corrective action to improve the quality of maintenance of building components of Ampel Mosque must be undertaken. The result of the gap determination is shown in Table 7.

Table 7. Gap value of user's satisfaction and expectations at Ampel Mosque Surabaya.

\begin{tabular}{|c|c|c|c|c|c|c|c|}
\hline \multirow{2}{*}{ No } & \multicolumn{2}{|c|}{ Mean Value } & \multirow{2}{*}{ Gap } & \multirow{2}{*}{ No } & \multicolumn{2}{c|}{ Mean Value } & \multirow{2}{*}{ Gap } \\
\cline { 2 - 3 } & KP & HP & & KP & HP & \\
\hline 1 & 3,703 & 3,712 & $-0,009$ & 16 & 3,489 & 3,766 & $-0,277$ \\
\hline 2 & 3,630 & 3,612 & 0,018 & 17 & 4,014 & 3,814 & 0,200 \\
\hline 3 & 3,852 & 3,827 & 0,025 & 18 & 3,648 & 3,602 & 0,046 \\
\hline 4 & 3,878 & 3,841 & 0,037 & 19 & 3,872 & 3,854 & 0,018 \\
\hline 5 & 3,885 & 3,765 & 0,120 & 20 & 3,858 & 3,818 & 0,040 \\
\hline 6 & 3,614 & 3,752 & $-0,138$ & 21 & 3,699 & 3,824 & $-0,125$ \\
\hline 7 & 3,619 & 3,824 & $-0,205$ & 22 & 3,576 & 3,855 & $-0,279$ \\
\hline 8 & 3,832 & 3,986 & $-0,154$ & 23 & 3,915 & 3,857 & 0,058 \\
\hline 9 & 3,729 & 3,911 & $-0,182$ & 24 & 3,845 & 3,822 & 0,023 \\
\hline 10 & 3,591 & 3,817 & $-0,226$ & 25 & 3,496 & 3,878 & $-0,382$ \\
\hline 11 & 3,878 & 3,775 & 0,103 & 26 & 3,673 & 3,681 & $-0,008$ \\
\hline 12 & 3,626 & 3,805 & $-0,179$ & 27 & 3,832 & 3,753 & 0,079 \\
\hline 13 & 3,419 & 3,332 & 0,087 & 28 & 3,612 & 3,624 & $-0,012$ \\
\hline 14 & 3,498 & 3,292 & 0,206 & 29 & 3,842 & 3,801 & 0,041 \\
\hline 15 & 3,544 & 3,890 & $-0,346$ & 30 & 3,667 & 3,955 & $-0,288$ \\
\hline
\end{tabular}


From Table 7, it appears that some variables have negative gap values between the satisfaction level (KP) and users' expectation (HP). The value of a significant gap will be used as a reference in preparing a technical response from the managers or administrators of the Ampel Mosque. Some of the variables with a gap value are not significantly combined with the technical response of a very significant gap value. Here are some technical responses (denoted by $\mathrm{R}$ ) of managers or administrators of Ampel Mosque to answer users' expectations (HP):

1. Ensuring equilibrium, strength, stability, proportionality, and configuration of the construction system (R-1)

2. Maintaining the durability of the structure against damage function and visual (R-2)

3. Ensuring the design and configuration of non-hazardous construction systems (R-3)

4. Ensuring the implementation and maintenance of non-hazardous construction (R-4)

5. Maintaining the comfort and regularity of space in and out of buildings physically and psychically (R-5)

6. Implementing an easy to understand and implemented maintenance method (R-6)

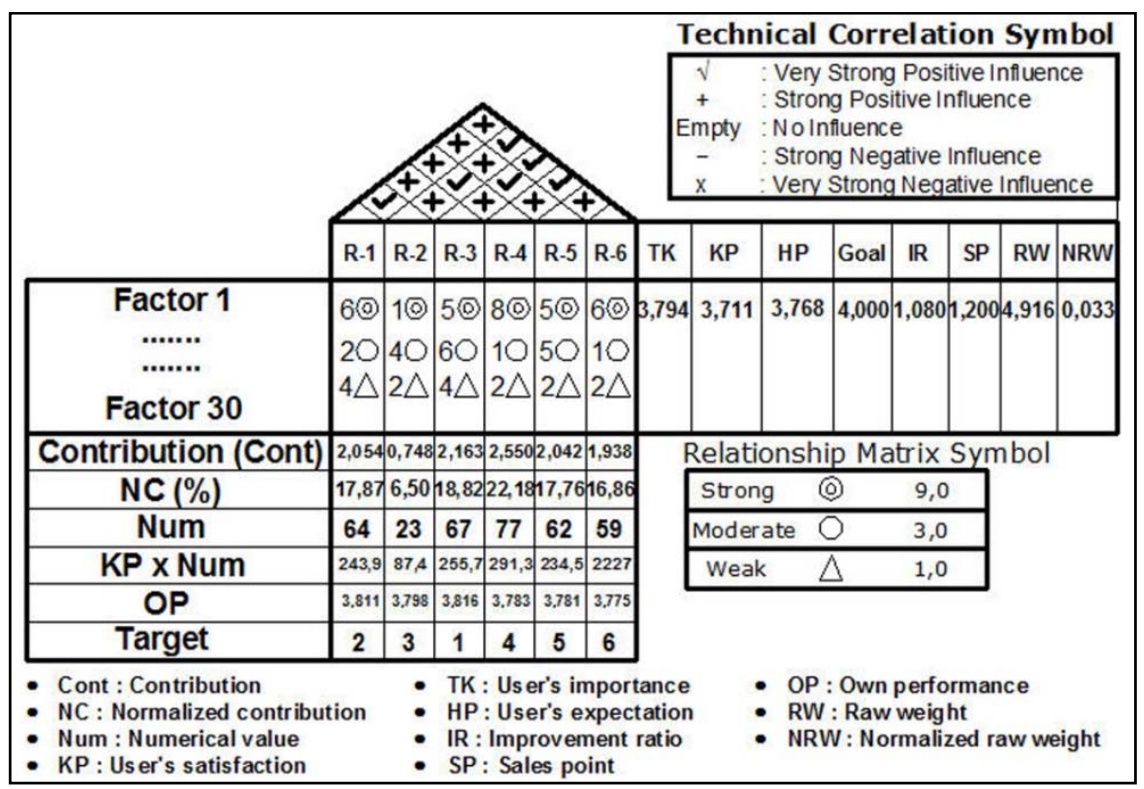

Fig. 7. The house of quality improvement target for Ampel Mosque Maintenance.

Six technical responses are included in the House of Quality (HoQ) to determine the target of improving the quality of maintenance of the building components of the Ampel Mosque. Figure 7 is the House of Quality for the targeting. The result of the QFD analysis by making a House of Quality as in Figure 7 can determine the target order of quality improvement of the building components of the mosque building based on the value of Own Performance (OP) on each technical response. The higher the OP value, the higher the target ranking. Targeting results based on OP are shown in Table 8. 
Table 8. Targets to improve the maintenance quality of Ampel Mosque Surabaya.

\begin{tabular}{|c|l|c|}
\hline Target & \multicolumn{1}{|c|}{ Technical Response } & OP \\
\hline 1 & $\begin{array}{l}\text { Ensuring the design and configuration of non-hazardous construction systems } \\
\text { (R-3) }\end{array}$ & 3,816 \\
\hline 2 & $\begin{array}{l}\text { Ensuring equilibrium, strength, stability, proportionality, and configuration of } \\
\text { the construction system (R-1) }\end{array}$ & 3,811 \\
\hline 3 & $\begin{array}{l}\text { Maintaining the durability of the structure against damage function and visual } \\
\text { (R-2) }\end{array}$ & 3,798 \\
\hline 4 & $\begin{array}{l}\text { Ensuring the implementation and maintenance of non-hazardous construction } \\
\text { (R-4) }\end{array}$ & 3,783 \\
\hline 5 & $\begin{array}{l}\text { Maintaining the comfort and regularity of space in and out of buildings } \\
\text { physically and psychically (R-5) }\end{array}$ & 3,781 \\
\hline 6 & $\begin{array}{l}\text { Implementing an easy to understand and implemented maintenance method (R- } \\
6)\end{array}$ & 3,775 \\
\hline
\end{tabular}

An affinity diagram is a diagram that describes the classification of a factor that is the focus of this research. Priority to improve the maintenance quality of the building of Ampel Mosque is obtained from the IPA stage by referring to the importance-satisfaction classification diagram, while the target of quality improvement of maintenance for the future is generated from the QFD stage with reference to the house of quality that has been formed. Priority in IPA is a high priority in the quadrant area A of the importance-satisfaction classification diagram, while the target is based on the value of the Own Performance (OP) of technical response within the house of quality. Furthermore, an affinity diagram is made containing classification of combined service factor based on priority $(\mathrm{P})$ improvement and target $(\mathrm{T})$ improvement of maintenance quality of the Ampel Mosque building. Figure 8 is a priority affinity diagram $(\mathrm{P})$ and target $(\mathrm{T})$ improving the maintenance quality of the Ampel Mosque building in Surabaya. The classification of the quality of the mosque construction of Ampel Mosque on an affinity diagram (Figure 8) consists of: Workability, Security and Safety, Serviceability, Comfort, Durability, and Maintainability.

\section{Workability:}

- Construction work (P)

- Construction equipment (P)

\section{Serviceability:}

- Ensuring equilibrium, strength, stability, proportionality, and configuration of the construction system (P \& T)

\section{Durability:}

- Durability to functional damage level (P\&T)

\section{Comfort:}

- Comfort and regularity of physical and psychic buildings (P\&T)

- Regularity of non-structural materials in construction systems (P)

\section{Security and Safety:}

- Design and configuration of nonhazardous construction systems (P \& T)

- Guarantee of free from physical and psyche construction function hazard $(\mathrm{P})$

\section{Maintainability:}

- Ease and affordability of maintenance (P)

- Implementation and maintenance of non-hazardous construction (P \& T)

- Maintenance methods are easy to understand and apply (P \& T)

Fig. 8. Affinity diagram to improve maintenance quality of Ampel Mosque Surabaya. 


\section{Conclusion}

The Ampel Mosque still retains much of the value of high local wisdom combined with other cultures. The authenticity of the mosque appears in the construction system of the supporting frame of the roof with timber material and brick walls. The reliability of the original mosque construction requires maintenance efforts. Research variables affecting maintenance quality include ease of workability, serviceability, durability, security, and safety, visual aesthetic of architectural systems and building construction material, comfort, and regularity, and ease and affordability in maintenance (maintainability). The results of the IPA analysis obtained 10 variables that received high priority for improvement, i.e.: Non-hazardous building materials, Design and configuration of non-hazardous construction system, Comfort and regularity of outdoor design, Durability to functional damage level, Stability of construction system, Implementation and maintenance of non-hazardous construction, Regularity system configuration and building construction, Maintenance methods are easy to understand and apply, Level of damage visually, and Comfort and regularity of physical and psychic building. Non-hazardous building material is the highest priority factor for improved maintenance. The second priority to be improved is the design and construction of a nonhazardous construction system. Quality Function Deployment (QFD) analysis yields 6 technical responses targeted to increase the maintenance effort of the Ampel Mosque building construction covers: Ensuring equilibrium, strength, stability, proportionality, and configuration of the construction system, Maintaining the durability of the structure against damage function and visual, Ensuring the design and configuration of non-hazardous construction systems, Ensuring the implementation and maintenance of non-hazardous construction, Maintaining the comfort and regularity of space in and out of buildings physically and psychically, and Implementing an easy to understand and implemented maintenance method. Technical response ensuring the design and configuration of nonhazardous construction systems is the highest target for improvement, while Maintaining the durability of the structure against damage function and visual is the second target to be improved. The management or administrators of the Ampel Mosque need to consider the priorities and targets of improving the maintenance of mosque building construction that has been obtained.

\section{References}

1. Wayne, B. Integrating LCA Tools in Green Building Rating Systems. Journal of Sustainable Materials. The ATHENA Sustainable Materials Institute. Ontario, Canada (2013)

2. Huda, Miftahul. Analysis of Important Factors Evaluation Criteria for Green Building. The International Journal of Engineering and Science (IJES) Volume 2 Issue 12 Pages 41-47 ISSN (e): 2319 - 1813 ISSN (p): 2319 - 1805 (2013)

3. Hariningsih, Franzeska. Physical facilities Influences on the Guests' Satisfaction at the Bidakara Hotel, Jakarta. Journal of Research Sahid University Jakarta (2013)

4. Abimaje et. al. An Assessment of Timber as a Sustainable Building Material in Nigeria. International Journal of Civil Engineering, Construction, and Estate Management (www.eajournals.org) (2014)

5. Carsten Hein, Arup. Developing Hybrid Timber Construction for Sustainable Tall Buildings. CTBUH Journal (2014)

6. Komalasari, Rahayu Indah. Green Building Assessment Based on Energy Efficiency and Conservation (EEC) Category at Pascasarjana B Building Diponegoro UniversitySemarang. American Journal of Energy Research, 2014, Vol. 2, No. 2, $42-46$ (2014) 
7. Adebara et. al. Quality and Utilization of Timber Species for Building Costruction in Minna Nigeria. The International Journal of Engineering and Science (IJES) ISSN(e): 2319-1813 ISSN(p): 2319-1805 (2014).

8. Sugiama, A Gima. The Synergistic Model of Quality Service Design of Green Open Space Asset Through QFD. The riset report at Politeknik Negeri Bandung (2015).

9. Kusumawardani, Rizka Pramita, Noviani, Suryasari, and Antariksa. Components of Facade Elements of Malang Great Mosque in 1910, 1940, and 2016. Http://arsitektur.studentjournal.ub.ac.id (2016).

10. Sedayu, Agung. Performance's Evaluation of Green Building in Islamic Boarding School. Presentation Material of Keynote Speaker. Proceeding of Scientific Meeting of IPLBI 2016 ITN Malang (2016).

11. Sedayu, Agung. Importance-Performance Analysis to Arjosari Terminal. DIMENSI Journal of Architecture and Built Environment, Vol. 41, No. 2, December 2014 ISSN 0126-219X (print)/ISSN 2338-7858 (online). Surabaya: Petra Christian University (2014).

12. Sedayu, Agung, et. al. Service Improvement of Joyoboyo Public Transport Terminal in Surabaya. Transylvanian Review Journal (indexed by Scopus, ISI Thomson Reuters, Copernicus, Social Sciences Citation Index, Arts and Humanities Citation Index, etc.) Maret 2016 ISSN 1221-1249 (2016).

13. Sugiyono. Statistics for Research. Bandung: publisher Alfabeta (2009). 